\title{
CMENTARZYSKO LUDNOŚCI KULTURY PUCHARÓW LEJKOWATYCH W MARIANOWIE, POW. KONIŃSKI, STAN. 17
}

\author{
CEMETERY OF THE FUNNEL BEAKER CULTURE \\ COMMUNITY IN MARIANOWO, KONIN COUNTY, SITE 17
}

\author{
Krzysztof Gorczyca \\ Muzeum Okręgowe w Koninie \\ ul. Muzealna 6, 62-510 Konin \\ krzysztof.gorczyca@muzeum.com.pl
}

\begin{abstract}
The cemetery in Marianowo is the first non-megalithic burial site of the Funnel Beaker culture (hereinafter referred to as TRB from German Trichterbecherkultur), which has been recorded in eastern Wielkopolska. It is also the first one where biritual funeral rites have been adopted. Despite the poor evidence, it might be generally dated to the Classic Wiórek phase (III), and even to sub-phase IIIC of TRB. All six unearthed burials were of children, and the question of the reason why one of them was cremated provides a wide range of interpretative alternatives.
\end{abstract}

KEY WORDS: Funnel Beaker culture, cremation, infant graves, Subneolithic.

Stanowisko znajduje się na terenie osady Szyszynek, należącej do sołectwa Marianowo, gmina Ślesin, pow. koniński na W od drogi do Wandowa (współrzędne geograficzne: $\mathrm{N} 52^{\circ} 25^{\prime} 7,38^{\prime \prime}$ E $18^{\circ} 17^{\prime} 8,83^{\prime \prime}$; obszar AZP 52-40; numer stanowiska na obszarze 115; działki ewidencyjne 156/1 i 156/4).

Położone jest na niewielkim piaszczystym wzniesieniu o wysokości względnej ok. 1,5 m. Na północ i wschód od niego występują oczka wytopiskowe, a na południe i zachód zmeliorowane obecnie łąki, przez które przepływa obecnie Kanał Szyszyński (ryc. 1). Dawniej był to strumień, który jeszcze w początkach XIX w. napędzał młyn Krupka w Ślesinie. Gleba w tym miejscu to silnie spiaszczona bielica. Omawiany teren należy do Pojezierza Kujawskiego, natomiast według podziału geomorfologicznego B. Krygowskiego (1961) znajduje się w obrębie Równiny Kleczewskiej. Równina ta rozcięta jest w układzie południkowym dwiema rynnami, które zajęte są przez misy jeziorne, tereny zatorfione oraz przepływające Strugi Biskupią (zachodnia) i Kleczewską (wschodnia). 


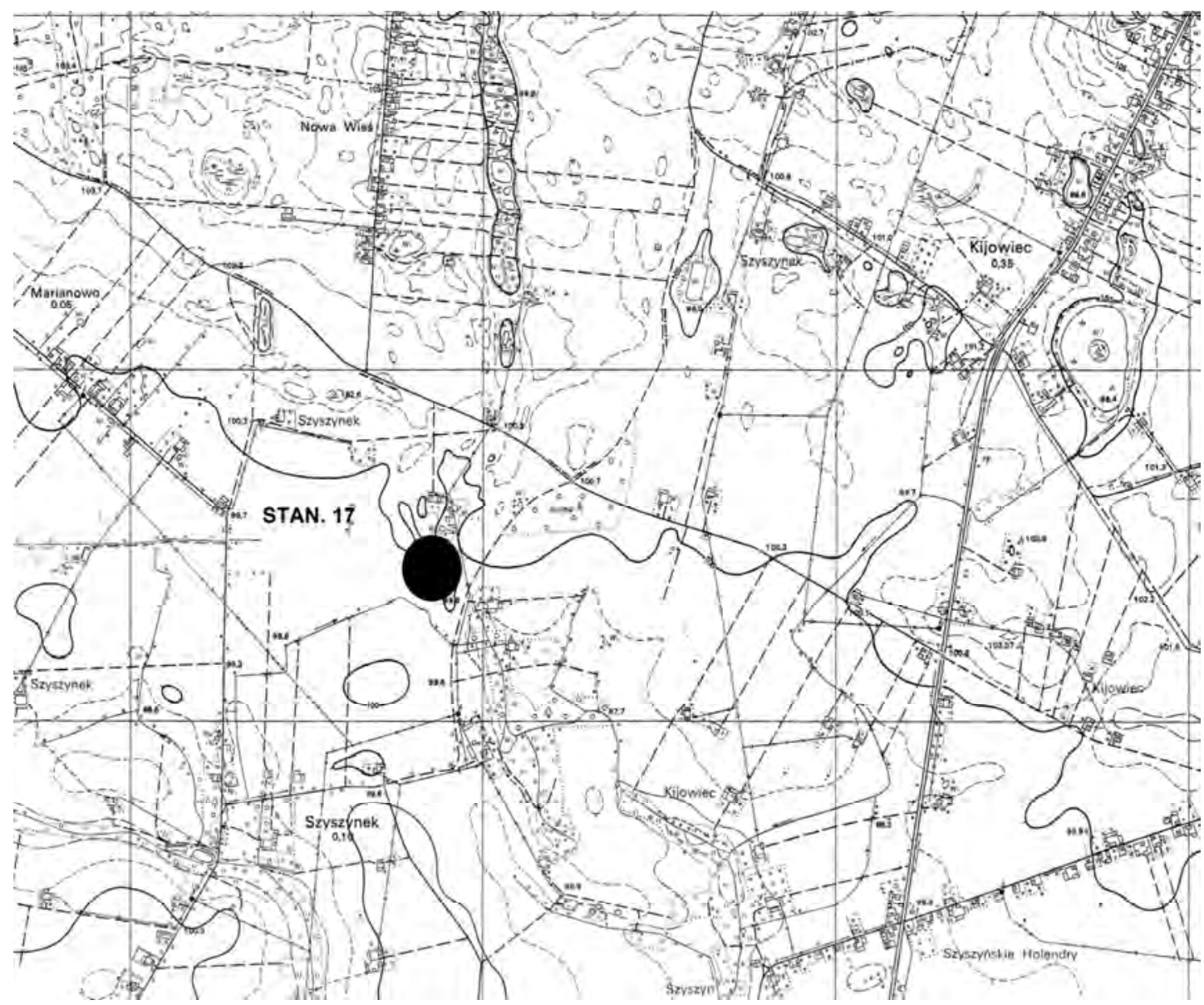

Ryc. 1. Marianowo, gmina Ślesin, pow. koniński, stan. 17. Lokalizacja stanowiska. Skala 1:10 000

Fig. 1. Marianowo, com. Ślesin, Konin county, site 17. Location of the site. Scale 1:10.000

\section{STAN BADAŃ}

Stanowisko zostało odkryte w trakcie badań AZP w 1987 r. Zebrano wówczas na nim materiał ceramiczny kultury pucharów lejkowatych (KPL), który znajduje się w Muzeum Okręgowym w Koninie (MOK), nr inw. MOK/A/3318. W 1988 r. w związku z zagrożeniem spowodowanym głęboką orką podjęto badania ratunkowe finansowane przez Muzeum Okręgowe w Koninie. Właścicielem pola był Pan Leszek Lewandowski, który z całą rodziną przez kolejne sezony wspierał prace ekspedycji. W tym miejscu serdecznie wszystkim dziękuję. 


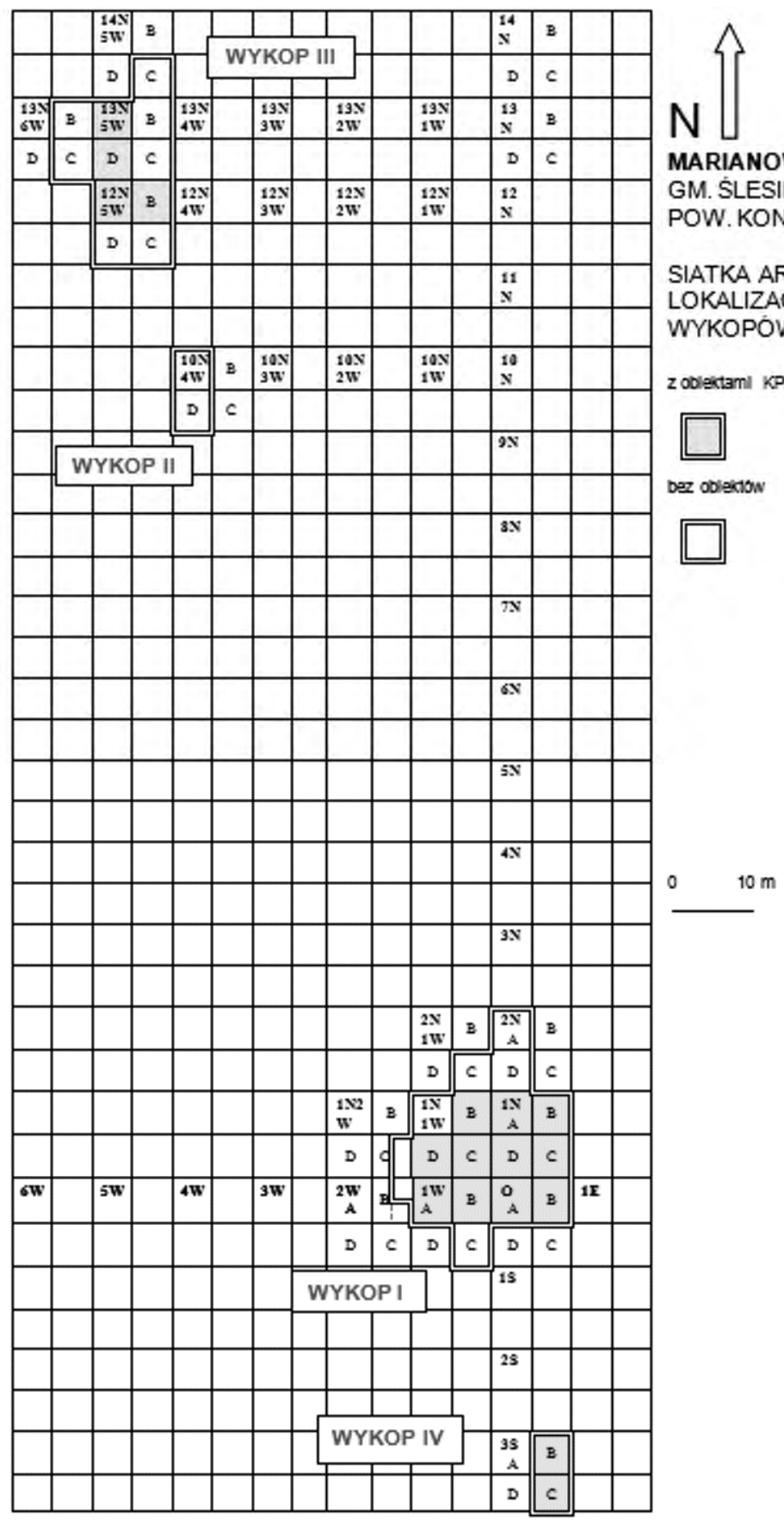

Ryc. 2. Marianowo, gmina Ślesin, pow. koniński, stan. 17. Rozplanowanie wykopów (rys. K. Gorczyca)

Fig. 2. Marianowo, com. Ślesin, Konin county, site 17. Layout of trenches (by K. Gorczyca) 
Badania prowadzono w sezonach 1988, 1989, 1990 i 1992. Stwierdzono, że orka zniszczyła całkowicie warstwę kulturową oraz częściowo stropy obiektów. Ruchomy materiał archeologiczny znajdował się $\mathrm{w}$ warstwie ornej, warstwie przemycia (niewiele) oraz w obiektach. Łącznie w 4 wykopach zbadano $825 \mathrm{~m}^{2}$ (ryc. 2).

Wykop I

Powierzchnia całkowita $450 \mathrm{~m}^{2}$. Zarejestrowano $\mathrm{w}$ nim ślady osady ludności KPL, złożonej z prostokątnej chaty $(8 \times 4 \mathrm{~m})$ o konstrukcji słupowej $(13$ dołków posłupowych) orientowanej EW, bliżej nieokreślonej zabudowy gospodarczej oraz kilka jam gospodarczych zawierających duże ilości ceramiki (ponad 4 tys. fragmentów) i polepy (ponad 1,5 tys. fragmentów). Znaleziono również wyroby krzemienne (ponad 160), żarna, rozcieracze, ciężarki tkackie i przęśliki. Na podstawie analizy materiału osadę można datować na fazę IIIC grupy wschodniej KPL. W ceramice wyraźnie zauważalny jest tzw. mątewski komponent kulturowy, występujący w tych samych obiektach co materiał KPL. Ta część stanowiska jest przedmiotem odrębnego opracowania.

W wykopie odsłonięto też relikty nowożytnej smolarni i kilka innych obiektów nowożytnych, w tym jeden zawierający szkielet krowy.

\section{Wykop II}

Powierzchnia $50 \mathrm{~m}^{2}$. Wytyczony w miejscu, w którym zaobserwowano na powierzchni skupienie materiału krzemiennego (głównie czekoladowego), m.in. dużą bułę (zaginęła) i siekierkę. Sugerowało to, że znajdowała się tu pracownia obróbki tego surowca. Obiektów jednakże nie zarejestrowano.

Wykop IV

Powierzchnia $50 \mathrm{~m}^{2}$. Wytyczony w miejscu, w którym zaobserwowano na powierzchni skupienie materiału ceramicznego i kamieni. Stwierdzono, że ta część stanowiska została zniszczona w czasach nowożytnych. Wszystkie odsłonięte obiekty pochodziły z tych czasów, m.in. doły śmietnikowe $\mathrm{z}$ lat międzywojennych.

\section{Wykop III}

Powierzchnia $275 \mathrm{~m}^{2}$. Wytyczony w miejscu, w którym według informacji właściciela pola było dużo kamieni przeszkadzających w orce.

Zarejestrowano tutaj cmentarzysko składające się z 6 grobów ludności KPL (ryc. 3) oraz 3 obiekty nowożytne wypełnione kamieniami. $Z$ powierzchni wykopu oraz z warstwy I i II zebrano ponad 800 fragmentów ceramiki, jednak ich cechy morfologiczne (m.in. fragmenty flaszy z kryzą), technologiczne oraz ornamentyka 


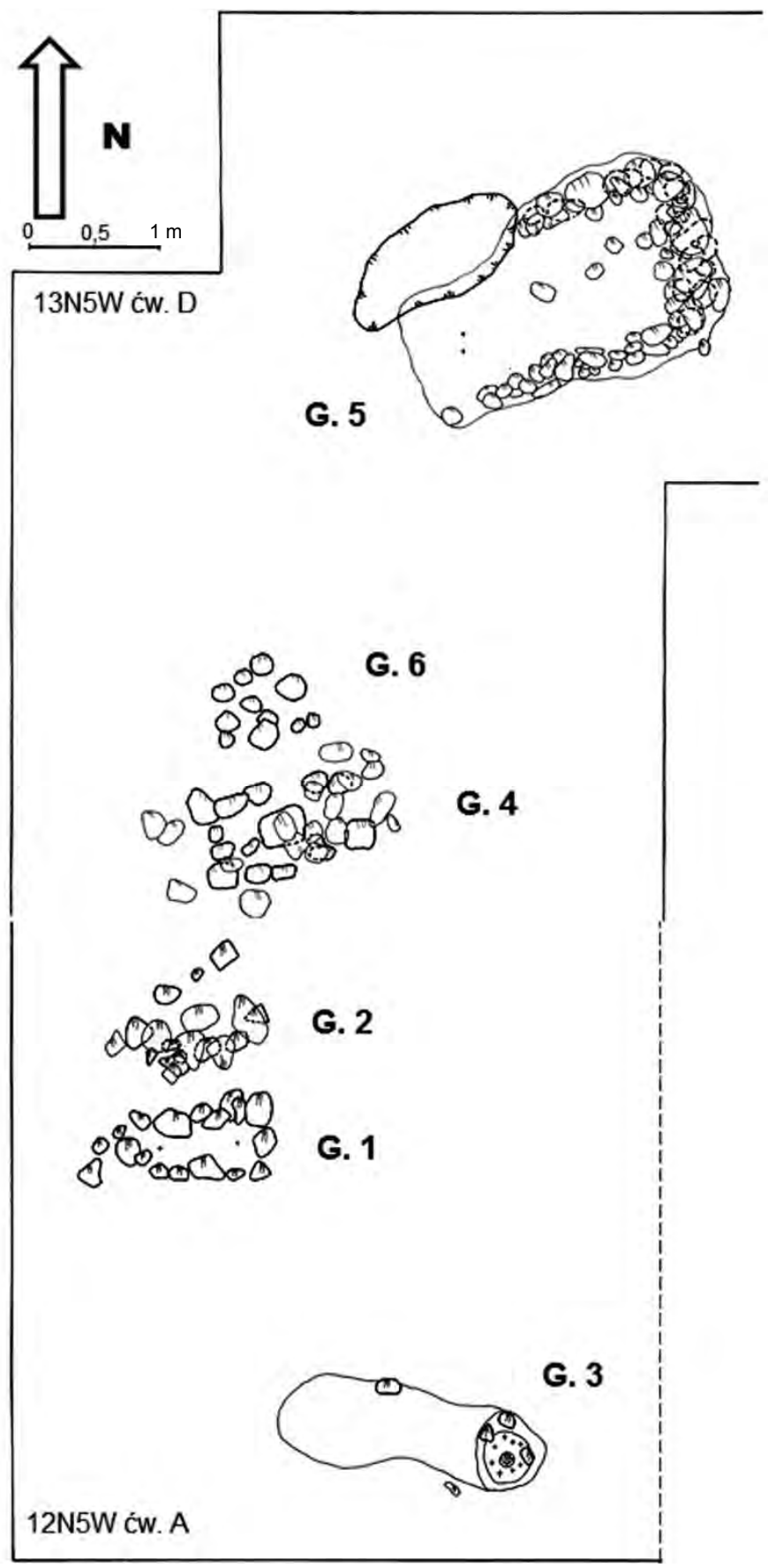

Ryc. 3. Marianowo, gmina Ślesin, pow. koniński, stan. 17. Rozplanowanie grobów (rys. K. Gorczyca)

Fig. 3. Marianowo, com. Ślesin, Konin county, site 17. Layout of graves (by K. Gorczyca) 

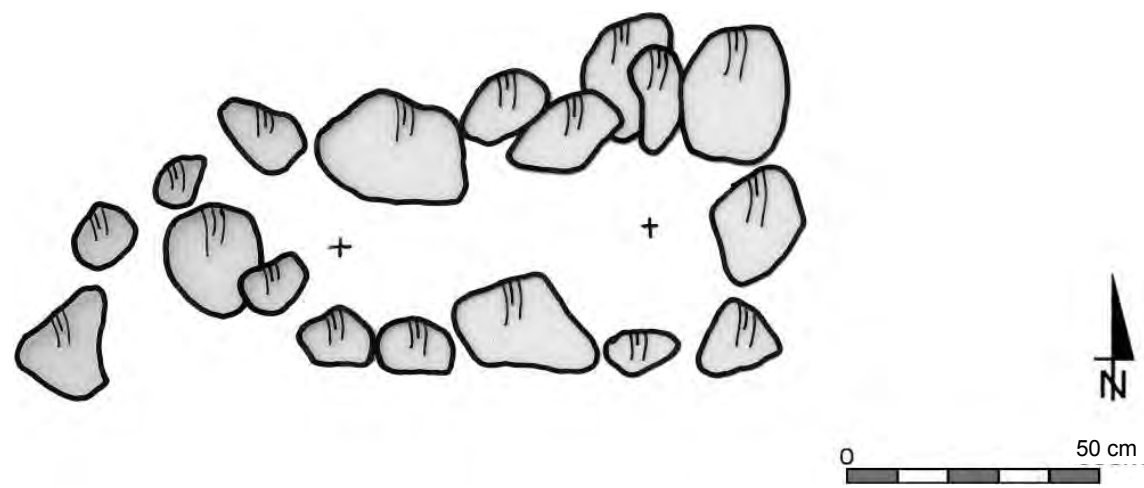

Ryc. 4. Marianowo, gmina Ślesin, pow. koniński, stan. 17. Grób 1. Rzut poziomy (rys. K. Gorczyca) Ryc. 4. Marianowo, com. Ślesin, Konin county, site 17. Grave 1. Layout (by K. Gorczyca)

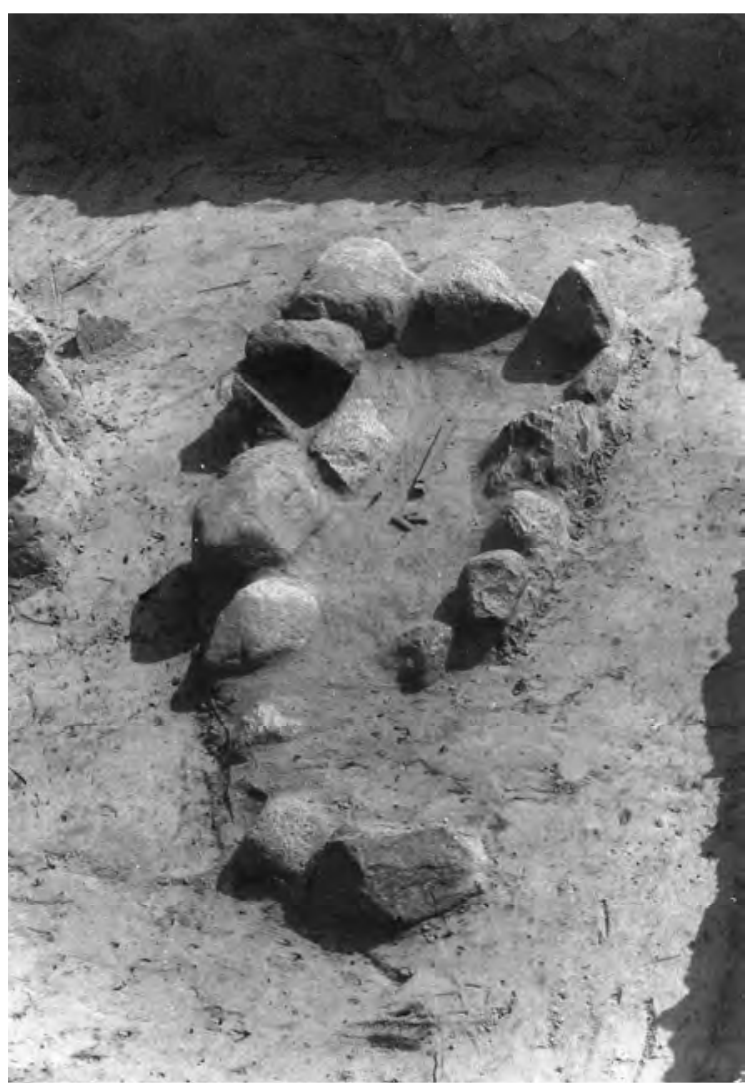

Ryc. 5. Marianowo, gmina Ślesin, pow. koniński, stan. 17. Grób 1. Rzut poziomy. Widok od S (fot. K. Gorczyca)

Fig. 5. Marianowo, com. Ślesin, Konin county, site 17. Grave 1. Layout. View to N, without cobblestones (photo by K. Gorczyca) 
wskazują, że pochodzą one z wcześniejszego okresu zasiedlenia stanowiska w fazie wczesnowióreckiej. Te znaleziska będą przedmiotem osobnego opracowania. Należy przyjąć, że nie mają one bezpośredniego związku z cmentarzyskiem.

\section{PRZEDSTAWIENIE ŹRÓDEL}

GRÓB 1 (ryc. 4, 5)

Jama: nieczytelna, obstawa kamienna trapezowata: $1,40 \times 0,70 \times 0,45 \mathrm{~m}$, głębokość $0,50 \mathrm{~m}$; orientacja - EW, podstawa na E.

Pochówek: szkieletowy - zaobserwowano kilka drobnych fragmentów silnie spróchniałych kości, lecz ze względu na zły stan nie udało się ich wydobyć; wiek - nieokreślony, płeć - nieokreślona (rozmiary obstawy wskazują, iż był to pochówek dziecka).

\section{Inwentarz:}

1. 1 fragment ceramiki

2. 1 odłupek krzemienny.

GRÓB 2 (ryc. 6, 7)

Jama: nieczytelna, przykryty był brukiem (prawdopodobnie zniszczonym w części $\mathrm{N}$ ), obstawa kamienna trapezowata: $1,10 \times 0,70 \times 0,60 \mathrm{~m}$, głębokość $0,50 \mathrm{~m}$; orientacja - NE-SW, odchylenie $35^{\circ}$ na N, podstawa na NE.

Pochówek: szkieletowy - zaobserwowano 2 drobne fragmenty silnie spróchniałych kości, lecz ze względu na zły stan nie udało się ich wydobyć; wiek - nieokreślony, płeć - nieokreślona (rozmiary obstawy wskazują, iż był to pochówek dziecka).

\section{Inwentarz:}

1. 2 fragmenty ceramiki

2. 1 odłupek krzemienny.

GRÓB 3 (ryc. 8, 9, 10)

Jama: a) podłużna, nieregularna, płytka jama: 2,05 ×0,60 m, głębokość $0,20 \mathrm{~m}$; jej wypełnisko to jasnoszara, silnie zbielicowana próchnica oraz jeden otoczak na obrzeżu, orientacja - EW, odchylenie $10^{\circ}$ na $\mathrm{S}$; b) na jej wschodnim końcu była kolista, nieckowata w przekroju jama o średnicy $0,50 \mathrm{~m}$ i głębokości $0,20 \mathrm{~m}$; jej wypełnisko to szara, silnie zbielicowana próchnica, ciemniejsza od poprzedniej; na jej obrzeżu znajdowały się trzy otoczaki, $w$ jamie zarejestrowano rozproszone nieliczne, przepalone kości; c) w centrum mniejszej jamy zaobserwowano skupisko przepalonych kości wymieszanych z niewielką ilością silnie rozdrobnionej spalenizny. 


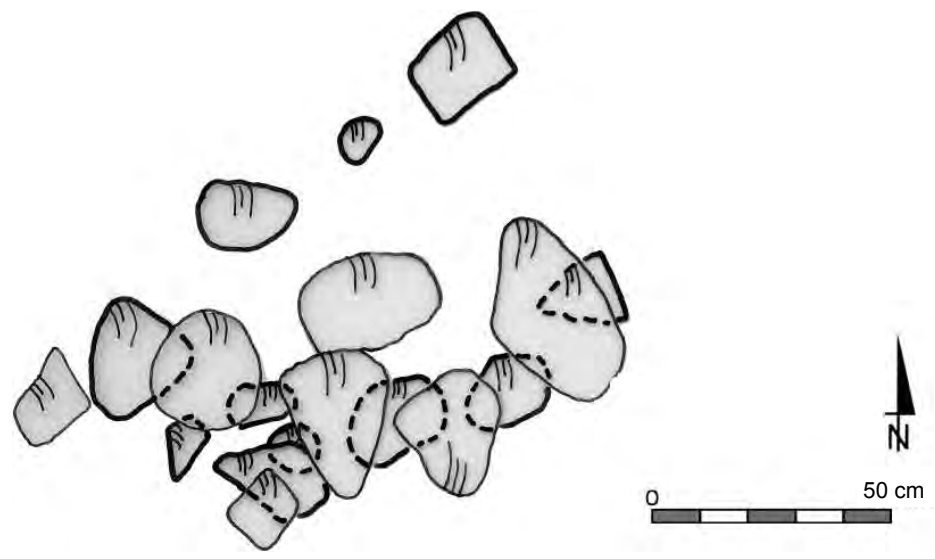

Ryc. 6. Marianowo, gmina Ślesin, pow. koniński, stan. 17. Grób 2. Rzut poziomy (fot. K. Gorczyca)

Fig. 6. Marianowo, com. Ślesin, Konin county, site 17. Grave 2. Layout (by K. Gorczyca)

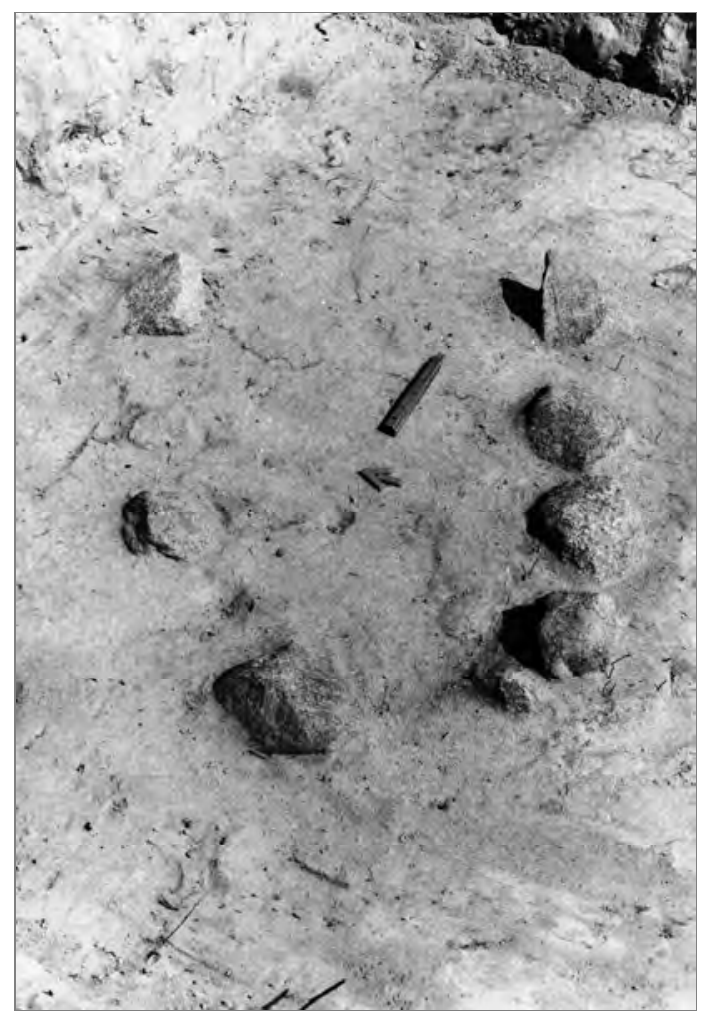

Ryc. 7. Marianowo, gmina Ślesin, pow. koniński, stan. 17. Grób 2. Rzut poziomy od S po zdjęciu bruku (fot. K. Gorczyca)

Fig. 7. Marianowo, com. Ślesin, Konin county, site 17. Grave 2. Layout, view to N, without cobblestones (photo by K. Gorczyca) 


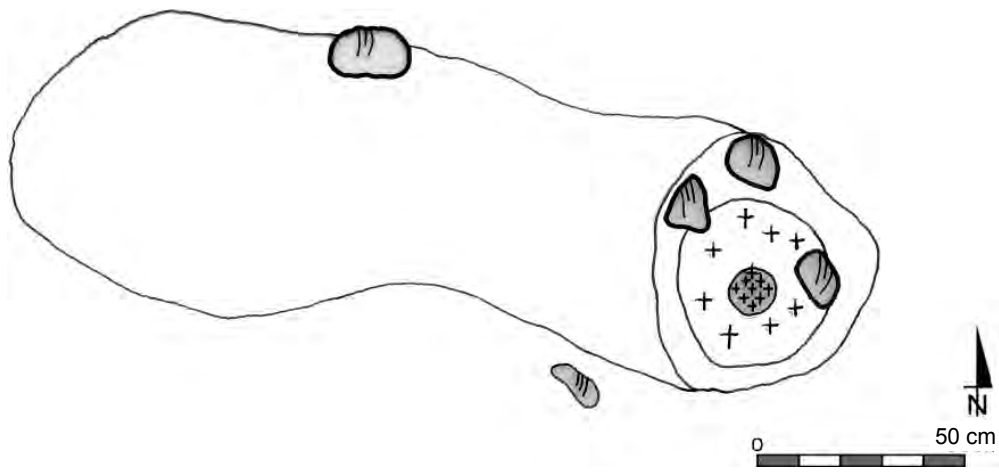

Ryc. 8. Marianowo, gmina Ślesin, pow. koniński, stan. 17. Grób 3. Rzut poziomy (rys. K. Gorczyca)

Fig. 8. Marianowo, com. Ślesin, Konin county, site 17. Grave 3. Layout (by K. Gorczyca)

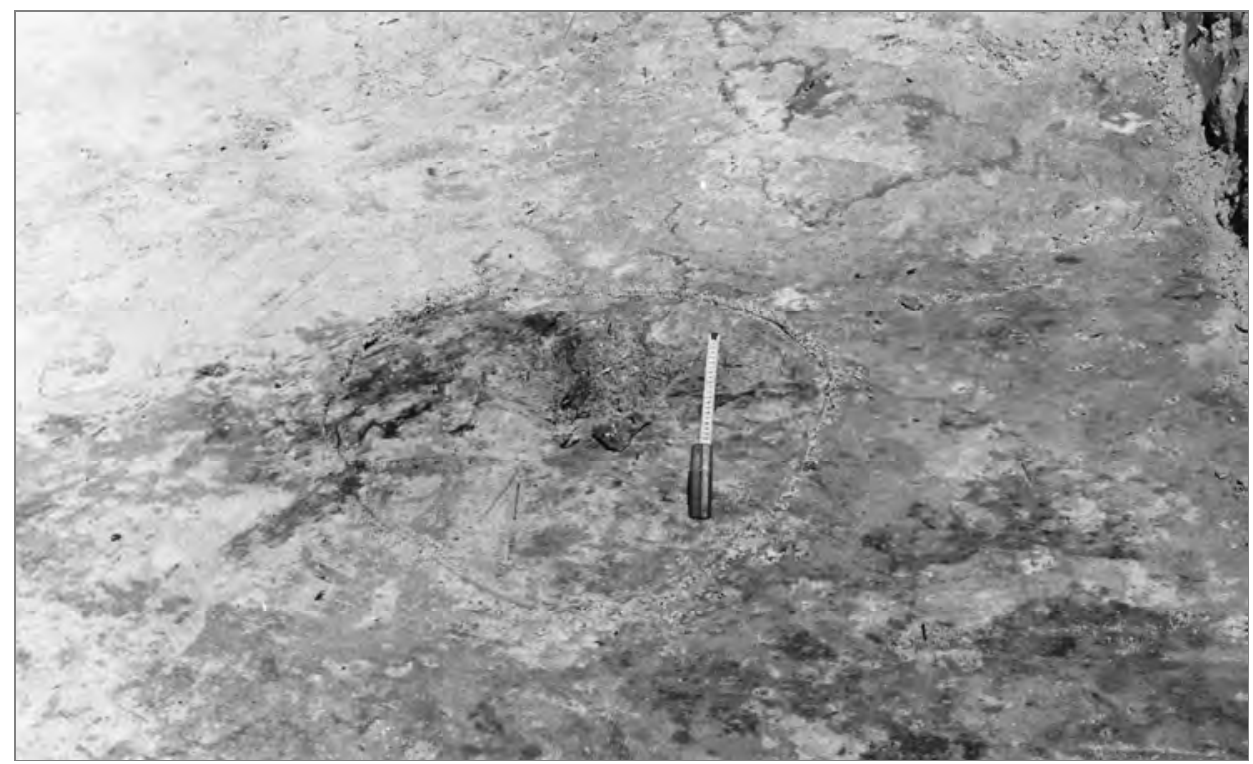

Ryc. 9. Marianowo, gmina Ślesin, pow. koniński, stan. 17. Grób 3. Rzut poziomy od S (fot. K. Gorczyca) Fig. 9. Marianowo, com. Ślesin, Konin county, site 17. Grave 3. Layout, view to N (photo by K. Gorczyca)

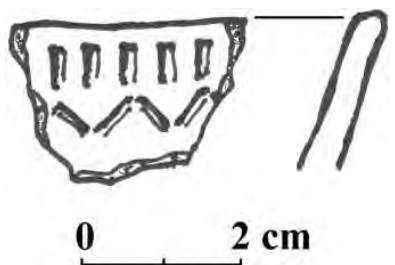

Ryc. 10. Marianowo, gmina Ślesin, pow. koniński, stan. 17. Grób 3. Fragment ceramiki (rys. K. Gorczyca) Fig. 10. Marianowo, com. Ślesin, Konin county, site 17. Grave 3. A fragment of pottery (by K. Gorczyca) 
Pochówek: ciałopalny ${ }^{1}$ - silnie przepalone kości ludzkie, barwy jasnopopielatej. Waga: $85 \mathrm{~g}$. To kości jednego osobnika, dziecka, i pochodzą ze wszystkich części szkieletu. Z czaszki: część łuski czołowej z ostrą krawędzią oczodołu, czołem gładkim. Ułamki sklepienia z wyraźnymi zagłębieniami szwów o ostrej krawędzi, o grubości kości 1-2 mm. Zarejestrowano delikatne i małe dwie (prawą i lewą) części skaliste kości skroniowych. Ze szkieletu postkranialnego: bardzo drobne fragmenty trzonów kości długich kończyn. Są to maleńkie kości bez nasad, drobne trzony i luźne nasady, nieprzyrosłe za życia. Średnica głowy kości udowej większa niż $20 \mathrm{~mm}$. Zachowało się 7 luźnych zębów: dwa mleczne zęby sieczne I1, trzy zęby mleczne trzonowe P2 i dwa wyrzynające się pierwsze stałe zęby trzonowe M1.

Wiek osobnika: dziecko Infans I, tj. ok. 5-6 lat, płeć - nieokreślona.

\section{Inwentarz:}

1. 1 fragment ceramiki

2. 4 fragmenty węgli drzewnych.

GRÓB 4 (ryc. 11, 12, 13)

Jama: nieczytelna, obstawa kamienna prostokątna: $1,4 \times 0,8 \mathrm{~m}$, głębokość $0,50 \mathrm{~m}$; orientacja-EW, odchylenie $15^{\circ}$ na N.

Pochówek: szkieletowy - zaobserwowano 1 drobny fragment silnie spróchniałej kości, lecz ze względu na zły stan nie udało się go wydobyć; wiek - nieokreślony, płeć - nieokreślona (rozmiary obstawy wskazują, iż był to pochówek dziec$\mathrm{ka})$.

\section{Inwentarz:}

1. 4 fragmenty ceramiki.

GRÓB 5 (ryc. 14, 15, 16)

Jama: trapezowata (częściowo zniszczona nowożytnym wkopem, pierwotnie być może prostokątna), nieckowata w przekroju: 2,50 × 1,60 × 1,10 m, głębokość $0,60 \mathrm{~m}$; orientacja - EW, odchylenie $25^{\circ}$ na $\mathrm{N}$; ściany wyłożone kamieniami, w części E - 4 warstwy, w części S - 2 warstwy; część W i NW pozbawiona kamieni przez wkop nowożytny.

Pochówek: szkieletowy. Znaleziono tylko fragmenty sklepienia czaszki o grubości kości 2-2,5 mm. Fragment prawej kości szczęki z tkwiącymi w niej zębami stałymi: kłem C, dwoma zębami przedtrzonowymi P1, P2 i zębem trzonowym M1 o słabo startych guzkach.

Zarejestrowano także 15 luźnych zębów stałych.Wydzielono z nich zęby strony lewej szczęki: drugi siekacz I2, kieł C, dwa zęby przedtrzonowe P1, P2 i pierwszy ząb trzonowy M1 o słabo startych guzkach; zęby żuchwy: dwa przedtrzono-

\footnotetext{
${ }^{1}$ Ekspertyzy dokonała A. Wrzesińska, za co składam jej serdeczne podziękowania (Wrzesińska 2006).
} 


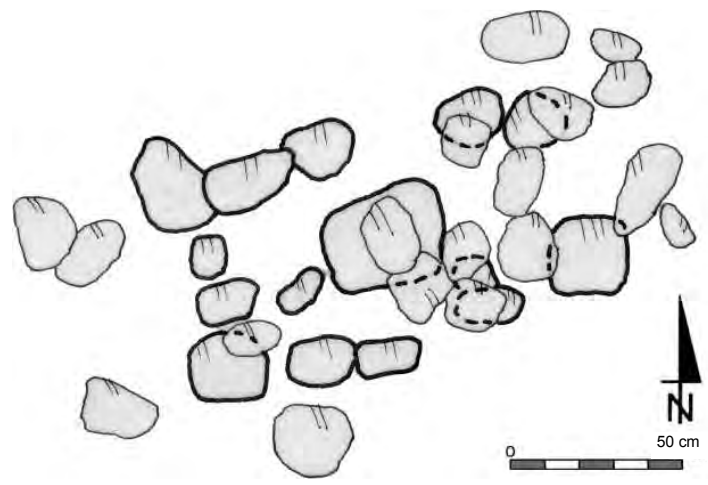

Ryc. 11. Marianowo, gmina Ślesin, pow. koniński, stan. 17. Grób 4. Rzut poziomy (rys. K. Gorczyca)

Fig. 11. Marianowo, com. Ślesin, Konin county, site 17. Grave 4. Layout (by K. Gorczyca)

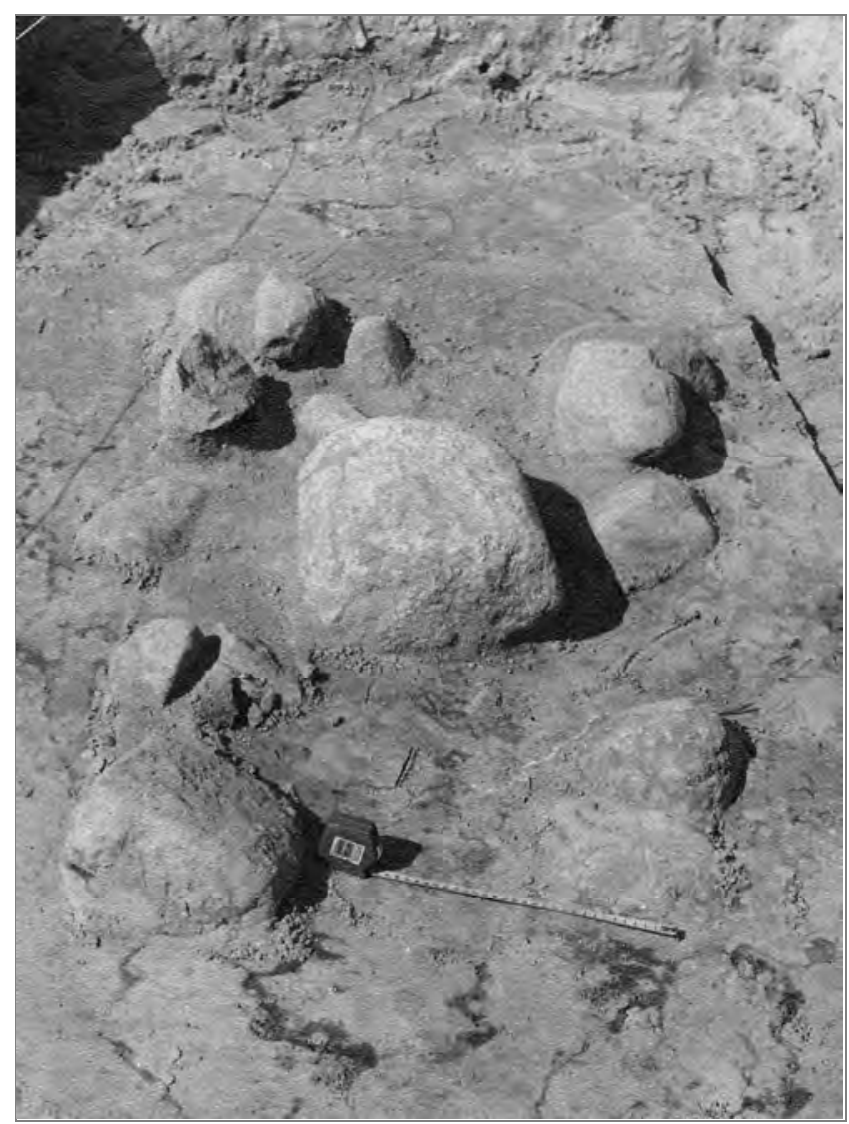

Ryc. 12. Marianowo, gmina Ślesin, pow. koniński, stan. 17. Grób 4. Rzut poziomy od E (fot. K. Gorczyca)

Fig. 12. Marianowo, com. Ślesin, Konin county, site 17. Grave 4. Layout, view to W (photo by K. Gorczyca) 


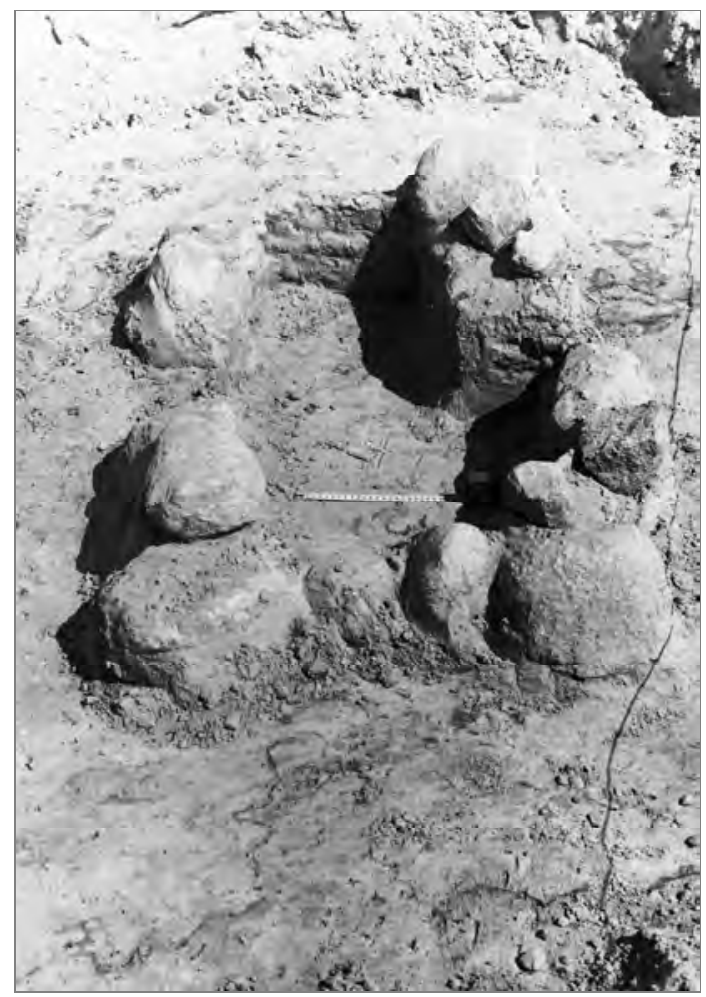

Ryc. 13. Marianowo, gmina Ślesin, pow. koniński, stan. 17. Grób 4. Rzut poziomy od W po zdjęciu bruku (fot. K. Gorczyca)

Fig. 13. Marianowo, com. Ślesin, Konin county, site 17. Grave 4. Layout, view to E, without cobblestones (photo by K. Gorczyca)

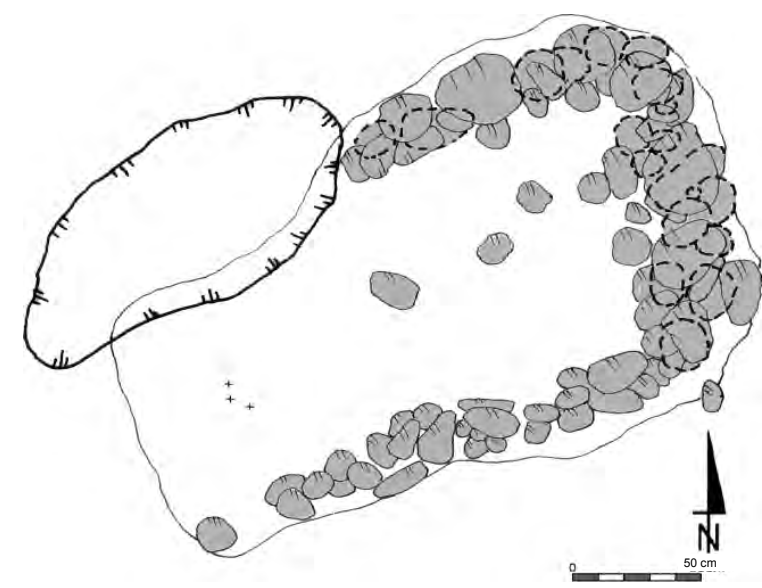

Ryc. 14. Marianowo, gmina Ślesin, pow. koniński, stan. 17. Grób 5. Rzut poziomy (rys. K. Gorczyca)

Fig. 14. Marianowo, com. Ślesin, Konin county, site 17. Grave 5. Layout (by K. Gorczyca) 


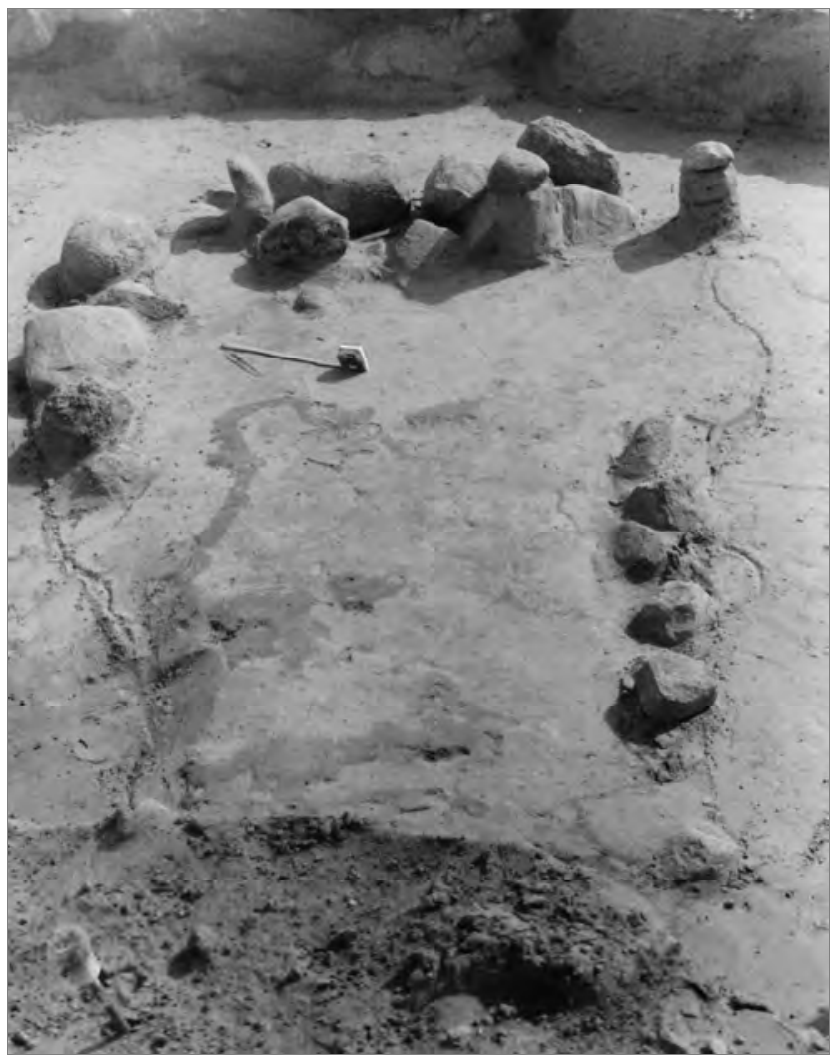

Ryc. 15. Marianowo, gmina Ślesin, pow. koniński, stan. 17. Grób 5. Rzut poziomy od W (fot. K. Gorczyca) Fig. 15. Marianowo, com. Ślesin, Konin county, site 17. Grave 5. Layout, view to E (photo by K. Gorczyca)

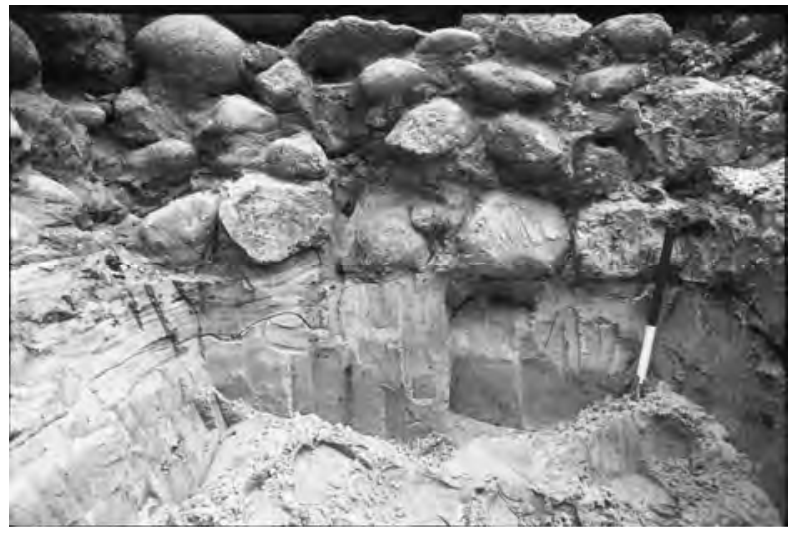

Ryc. 16. Marianowo, gmina Ślesin, pow. koniński, stan. 17. Grób 5. Ściana EN od W (fot. K. Gorczyca) Fig. 16. Marianowo, com. Ślesin, Konin county, site 17. Grave 5. EN wall, view to E (photo by K. Gorczyca) 
we P1 i dwa przedtrzonowe P2 oraz oba pierwsze zęby trzonowe M1 o słabszym starciu guzków niż zęby szczęki. Wydzielono również 4 zęby trzonowe M2 (ze szczęki i żuchwy) o braku starcia, dopiero wyrżnięte.

Wiek osobnika - dziecko Infans II, tj. ok. 12 lat, płeć - nieokreślona.

\section{Inwentarz:}

1. Pomiędzy kamieniami obstawy 2 fragmenty żaren.

GRÓB 6 (ryc. 17, 18)

Jama: nieczytelna, obstawa kamienna prostokątna: $0,8 \times 0,6 \mathrm{~m}$, orientacja $\mathrm{EW}$, odchylenie $35^{\circ}$ na N.

Pochówek: szkieletowy (?), brak kości; wiek - nieokreślony; płeć - nieokreślona (rozmiary obstawy wskazują, iż był to pochówek dziecka).

\section{Inwentarz:}

1. 4 fragmenty ceramiki.

Cmentarzysko prawdopodobnie było większe. Według informacji właściciela pola dawniej kamienie przeszkadzające w orce zbierało się i zakopywało. W pobliżu zarejestrowanych grobów odsłonięto takie 3 obiekty nowożytne wypełnione kamieniami. Niewykluczone jednak, że kamienie te pochodzą ze zniszczonych obiektów osadniczych wcześniejszej fazy zasiedlenia terenu, a nie z grobów.

Obiekt 38 (ar 12N5W, ćw. B)

Podłużna jama nowożytna: $0,80 \times 0,60 \mathrm{~m}$, zawierająca skupisko wtórnie wkopanych otoczaków. Brakuje materiału archeologicznego.

Obiekt 39 (ar 13N6W, ćw. C)

Nieregularna, głęboka jama. Średnica na stropie: $2 \mathrm{~m}$, na spągu ok. $1 \mathrm{~m}$, głębokość: $1 \mathrm{~m}$. Wypełniona była całkowicie kamieniami różnej wielkości. Wśród nich rozpoznano fragmenty 4 żaren nieckowatych, 4 żaren płaskich, 1 płytkę szlifierską, 1 rozcieracz. Między kamieniami 20 fr. ceramiki i 1 odłupek. Całość na wtórnym złożu.

Obiekt 52 (ar 14N5W, ćw. C)

Nieregularna jama. Średnica na stropie: $1 \mathrm{~m}$, na spągu ok. $1 \mathrm{~m}$, głębokość: 0,5 m. Wypełniona była całkowicie kamieniami różnej wielkości.

\section{ANALIZA MATERIALU}

Jedyny element inwentarza, który występuje prawie we wszystkich grobach, to fragmenty ceramiki naczyniowej. Łącznie zarejestrowano w nich zaledwie 8 sztuk. Znalezione odłupki z krzemienia bałtyckiego są mało charakterystyczne. 


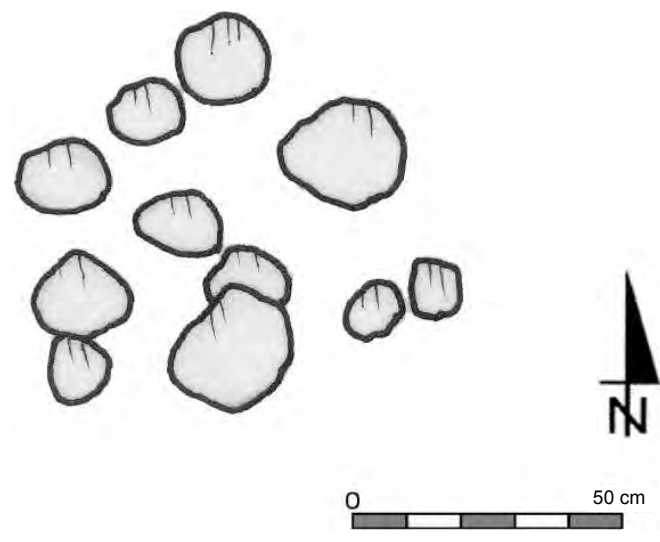

Ryc. 17. Marianowo, gmina Ślesin, pow. koniński, stan. 17. Grób 6. Rzut poziomy (rys. K. Gorczyca)

Fig. 17. Marianowo, com. Ślesin, Konin county, site 17. Grave 6. Layout (by K. Gorczyca)

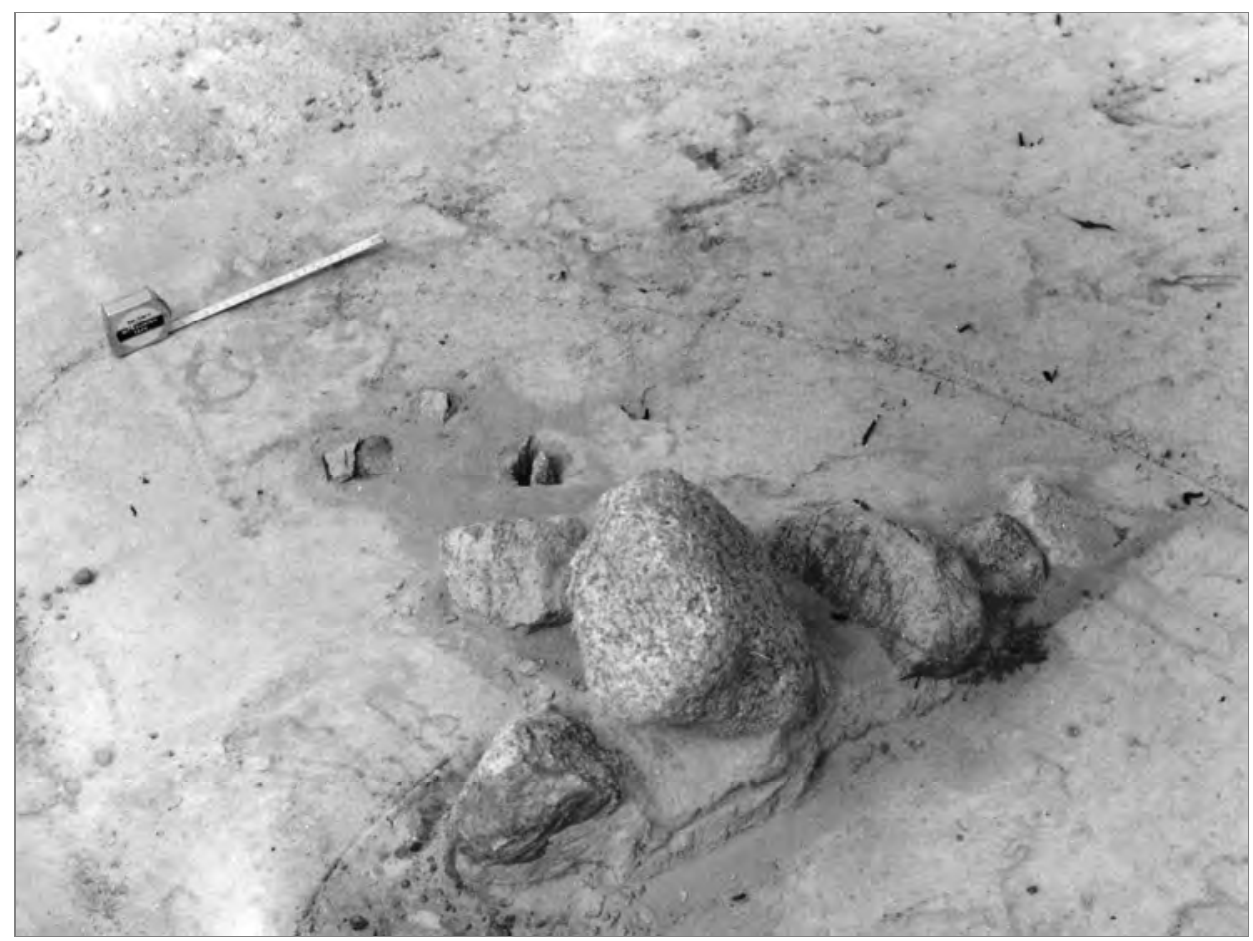

Ryc. 18. Marianowo, gmina Ślesin, pow. koniński, stan. 17. Grób 6. Rzut poziomy od E (fot. K. Gorczyca) Fig. 18. Marianowo, com. Ślesin, Konin county, site 17. Grave 6. Layout, view to W (photo by K. Gorczyca) 


\begin{tabular}{|c|c|c|c|c|c|c|c|}
\hline \multirow{2}{*}{ Lokalizacja } & \multicolumn{4}{|c|}{ Technologia $^{1}$} & \multicolumn{2}{|c|}{ Morfologia $^{2}$} & \multirow[t]{2}{*}{ Wątki zdobnicze } \\
\hline & G & B & D & I & $\mathbf{M k}^{3}$ & $\mathbf{M i}^{4}$ & \\
\hline Grób 1 & 7 & 4 & uv & 2 & $\mathrm{P}$ & & \\
\hline Grób 2 & $\begin{array}{l}7 \\
8 \\
\end{array}$ & $\begin{array}{l}4 \\
5 \\
\end{array}$ & $\begin{array}{l}\mathrm{uv} \\
\mathrm{uv}\end{array}$ & 2 & & & \\
\hline Grób 3 & 8 & 4 & uv & 2 & & $\mathrm{w}: 11 \mathrm{c}$ & pz: x A-1/B-16 \\
\hline Grób 4 & $\begin{array}{l}8 \\
8 \\
8 \\
7 \\
\end{array}$ & $\begin{array}{l}5 \\
5 \\
4 \\
4 \\
\end{array}$ & $\begin{array}{l}\text { uvw } \\
\text { uv } \\
\text { uvw } \\
\text { uv }\end{array}$ & $\begin{array}{l}2 \\
2 \\
2 \\
2 \\
\end{array}$ & & & \\
\hline Grób 5 & - & - & - & - & & & \\
\hline Grób 6 & $\begin{array}{l}8 \\
7 \\
8 \\
7 \\
\end{array}$ & $\begin{array}{l}5 \\
5 \\
5 \\
5 \\
\end{array}$ & $\begin{array}{l}\text { uv } \\
\text { uv } \\
\text { uv } \\
\text { uv }\end{array}$ & $\begin{array}{l}2 \\
2 \\
2 \\
2\end{array}$ & & & \\
\hline
\end{tabular}

Legenda

1. Opis technologii ceramiki wg: Wierzbicki 1999, s. 53, tab. 4. Skróty: G - grubość ścianki (w mm), B - barwa przełamu, D - domieszka, I - ilość domieszki.

2. Opis morfologii wg: Wierzbicki 1999, s. 58, ryc. 18, tab. 6, s. 59, ryc. 19.

3. Mk - makromorfologia. Skróty: A - amfora, K - kubek, M - misa, P - puchar.

4. Mi - mikromorfologia. Skróty: d - dno, ps/b - przejście szyjki w brzusiec, sz - szyjka, u - ucho, w - wylew.

5. Zapis zdobnictwa - wg: Kośko i Prinke 1977, s. 16-19; Kośko 1981, s. 34 42; z uzpehnieniami Wierzbicki 1999, s. $72-73$.

\section{CHRONOLOGIA}

Jedynym elementem stwarzającym możliwości datowania jest znaleziony w grobie 3 fragment wylewu zdobiony wątkiem pionowych słupków podkreślonych odciskanym zygzakiem (ryc. 10). Powszechnie przyjmuje się, że ornament ten wyznacza klasyczną (III) fazę wiórecką (Wierzbicki 2013, s. 118). Szczegółowa chronologia poszczególnych grobów na cmentarzysku, ze względu na brak elementów pozwalających na ich datowanie, pozostaje sprawą otwartą.

Nie wiemy, kiedy powstało cmentarzysko w Marianowie, ale najprawdopodobniej należy je powiązać z drugą fazą zasiedlenia stanowiska, kiedy zamieszkiwana była osada uchwycona w wykopie I. Jak wspomniano, jest ona przedmiotem odrębnego opracowania. Wyprzedzając tę publikację, można stwierdzić (na podstawie obecności w zdobnictwie ceramiki elementów komponentu wielkopolskiego w wersji epiwióreckiej, a braku zdobnictwa sznurowego), że czas użytkowania tej osady zamyka się w ramach podfazy IIIC, czyli ok. połowy IV tysiąclecia przed naszą erą (Wierzbicki 2013, s. 128-129, 156).

\section{ANALIZA ELEMENTÓW OBRZĄDKU POGRZEBOWEGO}

Powszechnie wiadomo, że obrządek pogrzebowy składał się i składa zawsze z wielu etapów i rytuałów (Pearson 2000). Można analizować tylko te elementy, które są uchwytne poprzez obserwacje w trakcie badań archeologicznych. 


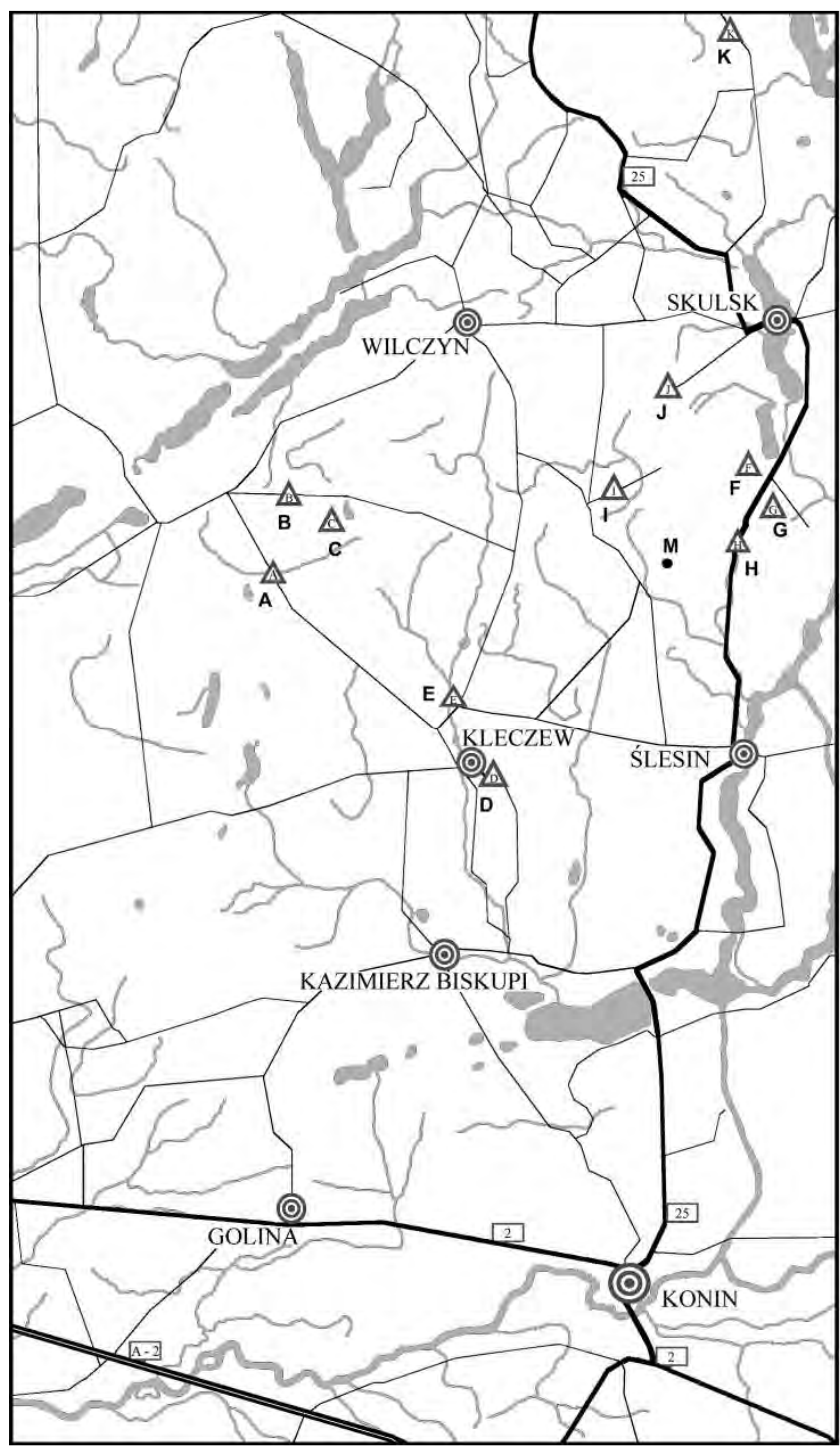

\section{LEGENDA}

sieć hydrograficzna

sieć drogowa

25 drogi główne

(2) większe miejscowości

$\triangle$ stanowiska megalityczne:

A - Nieborzyn, B - Zebrzyn,

C-Zberzynek, D - Kleczew,

E - Rostoka, F- Celinowo

(Dąb), G - Celinowo,

H - Kijowiec, I - Ościsłowo,

J - Buszkowo, K - Rzeszynek

M - Marianowo

Ryc. 19. Marianowo, gmina Ślesin, pow. koniński, stan. 17. Lokalizacja cmentarzyska na tle mapy kleczewskiej enklawy grobowców kujawskich (rys. P. Gaj)

Fig. 19. Marianowo, com. Ślesin, Konin county, site 17. Location of the cemetery on the map of the Kleczew enclave of Kujavian graves (by P. Gaj)

\section{Lokalizacja}

Cmentarzysko marianowskie zlokalizowano we wschodniej partii kleczewskiej enklawy grobowców kujawskich (Gorczyca 2005); do pobliskich cmentarzysk w Kijowcu, stan. 4, czy w Ościsłowie, stan. 5, jest zaledwie kilka kilometrów. To 
pierwsze na tym terenie prawdopodobnie typowe dla swoich czasów cmentarzysko zwykłych członków społeczności KPL, w odróżnieniu od cmentarzysk z grobowców kujawskich przeznaczonych dla wybitnych członków społeczności. Przeprowadzone w ramach AZP badania powierzchniowe na terenie enklawy ujawniły ponad 550 stanowisk osadniczych związanych z KPL. Liczba ta wskazuje, jak niewiele jeszcze wiadomo na temat cmentarzysk tej ludności.

Ślady starszego osadnictwa na stanowisku wskazują, że prawdopodobnie było to miejsce pozbawione drzew i większych krzewów, a zatem niestwarzające ograniczeń w kwestii lokalizacji i rozplanowania. Ułatwiło to niewątpliwie rozmieszczenie nowej osady, a także pozwalało uniknąć nagromadzenia obiektów grobowych (Buśko 1987, s. 61).

Cmentarzysko znajdowało się w pobliżu zabudowań jednodworczej osady $130 \mathrm{~m}$ na NNW od niej. Nasuwa to przypuszczenie, że miało ono charakter ",rodzinny”, że było przeznaczone tylko dla mieszkańców tego „domu z podwórzem” (Grygiel 1986, s. 43-334). Ewidentne ślady działania ognia we wszystkich obiektach osady - przepalony piasek, polepa, ceramika pozwalają wnioskować, że w zagrodzie był pożar, przy czym większość dobytku pozostała na miejscu. Z kolei brak śladów przebudowy i napraw zdaje się wskazywać, że była zamieszkiwana przez krótki okres (1 pokolenie?). Pośrednio wskazują na to również niewielkie rozmiary cmentarzyska.

Groby położone były na północny zachód od zabudowań, czyli w kierunku uważanym w wielu kulturach i czasach za „nieczysty” (Woźny 2000, s. 145). Nie wiemy, czy było to związane w jakiś sposób z wierzeniami. Brak większego materiału porównawczego nie pozwala na analizę.

\section{Rozplanowanie grobów}

Groby marianowskie mają układ rzędowy, w miarę regularny. Są to cechy typowe dla cmentarzysk złożonych zarówno z grobów płaskich (Rzepecki 2004, s. 121-122), jak i grobowców kujawskich, jak choćby z pobliskiego Zberzyna czy Ościsłowa (Gorczyca, 2005).

\section{Orientacja grobów}

Orientacja grobów jest prawie jednakowa i ogólnie zbliżona do osi E-W, co jest typowym zjawiskiem. Układ kamieni w grobach trapezowatych wskazuje, że zmarli byli układani głową na E. Jednakże w grobie 5 stwierdzono, że głowa znajdowała się w części W. Nie wiadomo, czy było to związane z płcią, czy wiekiem zmarłego. Odchylenia od osi thumaczy się tym, że w orientowaniu grobów najprostszym sposobem było wyznaczenie azymutu według punktu na horyzoncie, w którym wschodziło słońce. Punkt ten w zależności od pory roku zmienia się, a więc zmieniają się również orientacje grobów. Na tej podstawie, znając azymuty wschodów słońca w poszczególnych miesiącach, można określić, w którym miesiącu odbył się po- 
grzeb konkretnego osobnika (Jakimowicz 1936, s. 29). Czyniono wcześniej takie próby w odniesieniu do cmentarzyska wczesnośredniowiecznego w Końskich. Korzystając z tych ustaleń, zbudowano wykres obrazujący roczny przebieg zgonów badanej grupy ludzkiej, tzw. drzewko wymieralności (Januszewski 1968, s. 265-270), dość zbliżone do współczesnego. Liczba grobów w Marianowie jest jednak zbyt mała, aby uzyskać jakieś statystycznie istotne wyniki takich analiz.

\section{Zróżnicowanie form grobów}

Forma grobów - groby płaskie z pochówkiem na wznak i zabezpieczeniem kamiennym w postaci obstawy i (lub) bruku należą od dawna do uznawanych za typowe dla KPL (Jażdżewski 1936). Różnice pojawiają się w szczegółach, ale nie wiadomo, jakie są ich przyczyny. Na cmentarzysku w Marianowie odsłonięto 6 grobów, każdy o nieco innej konstrukcji:

1. obstawa trapezowa przypominająca kształtem grobowiec kujawski (G1)

2. obstawa trapezowata przykryta brukiem $(\mathrm{G} 2)$

3. obstawa prostokątna przykryta brukiem (G4)

4. prostokątny bruk (G6)

5. trapezowata (pierwotnie prawdopodobnie prostokątna) jama o ścianach wyłożonych kamieniami (tzw. suchy mur) (G5)

6. podłużna, owalna, płytka jama, na której E końcu kolista, nieckowata w przekroju jama z ciałopalnym pochówkiem (G3).

Cztery pierwsze groby nie różnią się od innych znanych w grupie wschodniej KPL, czy to na Kujawach (Rybicka 1995, s. 71; Rzepecki 2004, s. 121-122), Ziemi Chełmińskiej (Gurtowski 1987, s. 175-181; Kukawka i Wawrzykowska 1990, s. 40-44; Marciniak 1987, s. 167-174), czy na innych terenach (Baczyńska 1984, s. 21-28; Bukowska-Gedigowa 1975, s. 83-186). Najbliższy odpowiednik konstrukcji typu 3 (G4) to grób w grobowcu kujawskim I w Ościsłowie, gm. Wilczyn, pow. Konin, stan. 5 (Gorczyca 2008) (ryc. 20, 21).

Groby o ścianach wykładanych kamieniami (tzw. suchy mur) są dość rzadkie, ale występują na wielu terenach, takich jak Małopolska (Bargieł i Florek 2005, s. 20-32; Kozak-Zychman i Szeliga 2005, s. 33-41; Nogaj-Chachaj 1991, s. 628-639) czy Pomorze (Wierzbicki 1994, s. 5-58).

Absolutnym wyjątkiem w Marianowie jest grób ciałopalny. Jego większa jama przypominała płytką jamę grobów szkieletowych (np. Baczyńska 1984, s. 23), ale nie znaleziono $\mathrm{w}$ niej kości. $\mathrm{W}$ jej części wschodniej znajdowała się mniejsza jama z pochówkiem ciałopalnym. Nie wiemy, czy był to grób podwójny, czy też symboliczny. Najbliższym skojarzeniem jest grób w Małem Czystem, gm. Stolno, gdzie też odkryto dwuczęściową jamę, jednakże jej wypełnisko i układ kości są odmienne (Gurtowski 1987, s. 175-181; Kukawka i Wawrzykowska 1990, s. 40-44). 


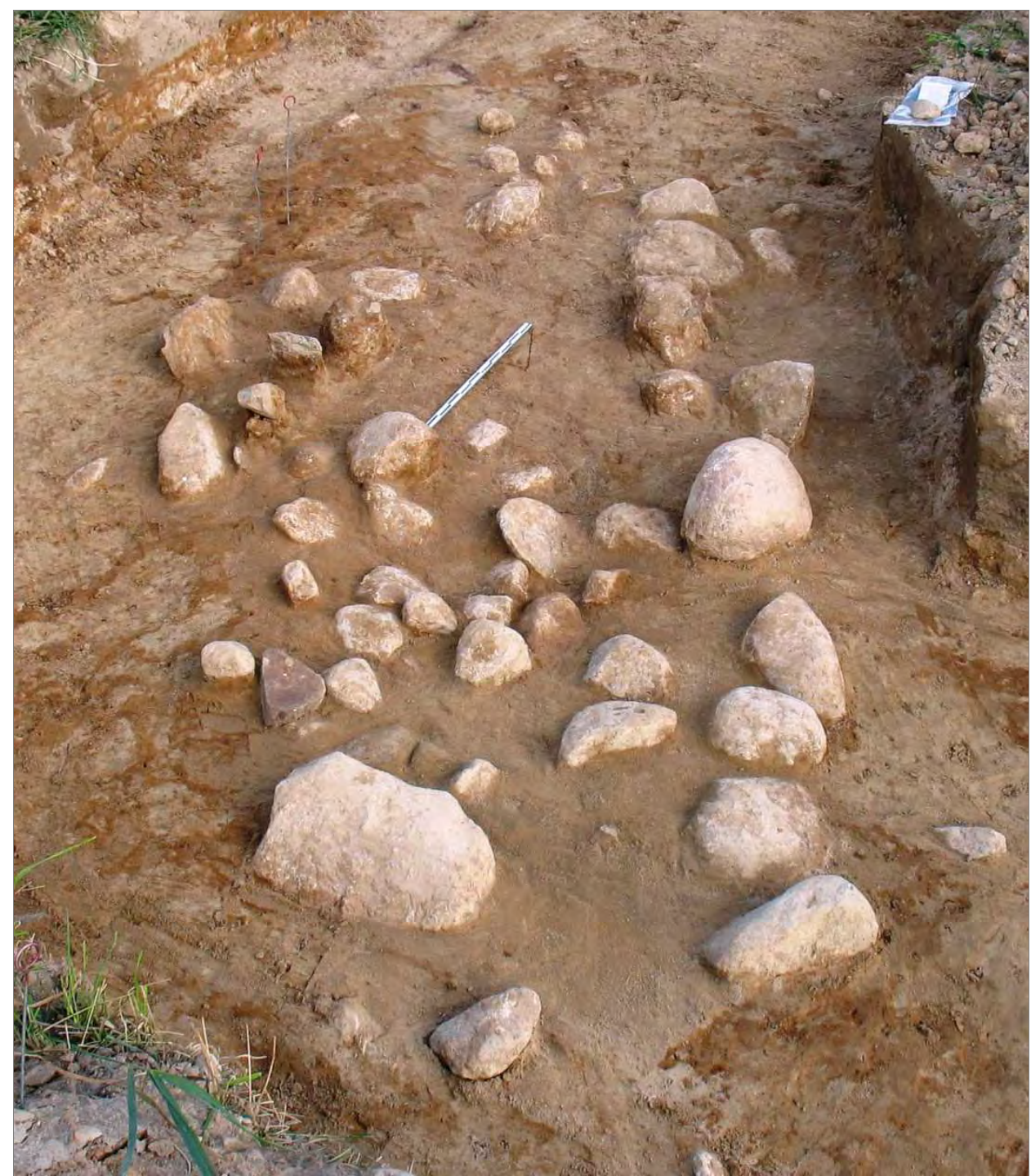

Ryc. 20. Ościsłowo, gmina Wilczyn, pow. koniński, stan. 5. Grobowiec I. Rzut poziomy od SE (fot. K. Gorczyca)

Fig. 20. Ościsłowo, com. Wilczyn, Konin county, site 5. Barrow I. Layout, view to NW (photo by K. Gorczyca)

Jak wiadomo, przeważającą formą pochówku zmarłych w KPL jest inhumacja (Wiślański 1979, s. 251-260). Pochówki ciałopalne pojawiają się co prawda bardzo rzadko, na prawie całym obszarze zajmowanym przez tę kulturę, prawdopodobnie jedynie z wyjątkiem Skandynawii. W Polsce spotyka się je na Kujawach i Ziemi 
Chełmińskiej, na Lubelszczyźnie, na Dolnym i Górnym Śląsku. Ostatnio znane groby ciałopalne KPL zebrał J. Wierzbicki przy okazji omawiania cmentarzyska w Konarzewie, pow. Poznań, stan. 5. Jego zdaniem jedynie na Pomorzu Środkowym oraz w późnych fazach KPL na Górnym Śląsku i Morawach zwyczaj ciałopalenia nabiera cech obrządku panującego. Pojawienie się ciałopalenia wśród społeczeństw KPL na tym terenie można wiązać z wpływami ludności kultury ceramiki promienistej, w której stosowanie tego obrządku było bardzo popularne (Wierzbicki 2008, s. 25-55).

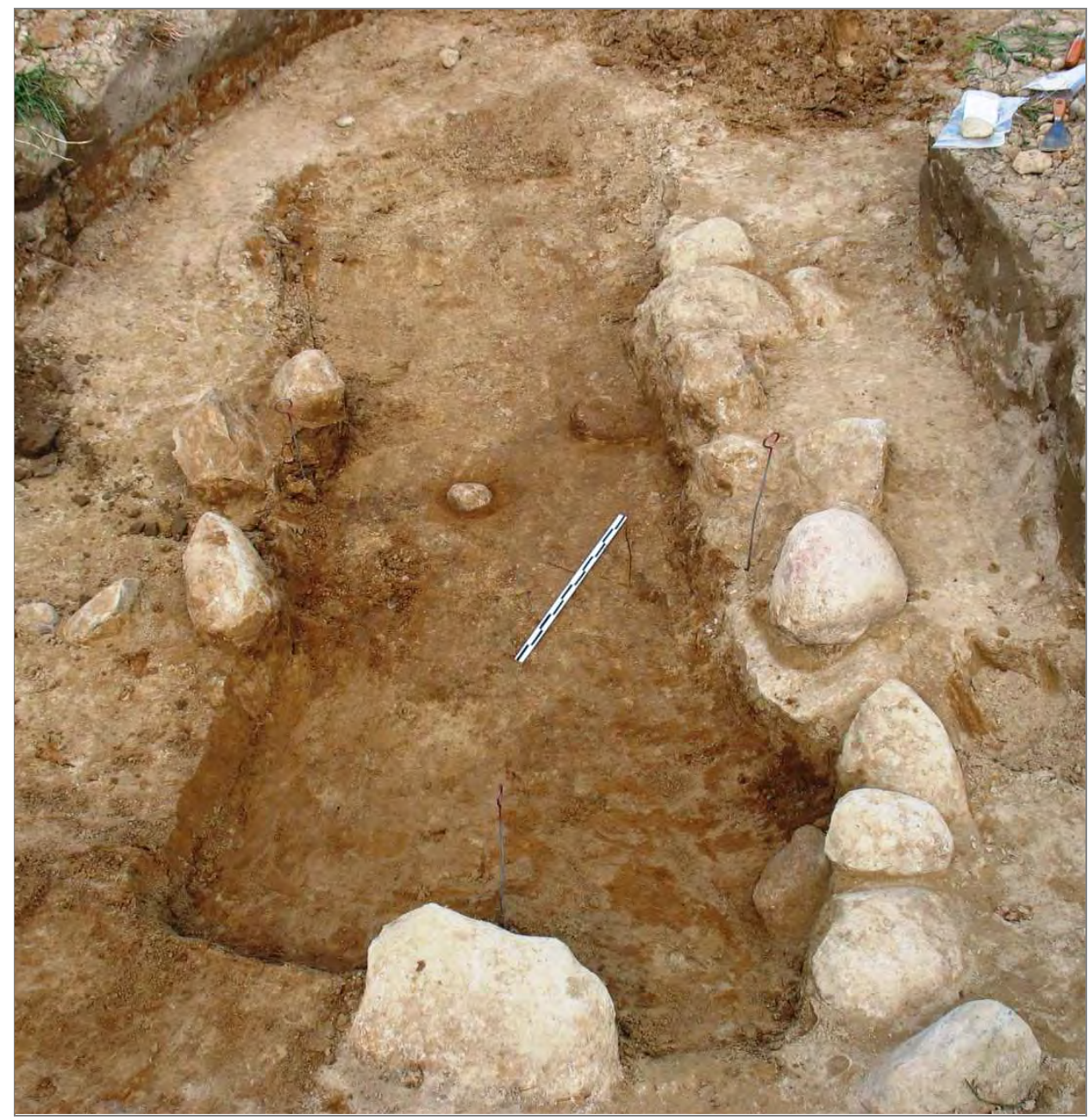

Ryc. 21. Ościsłowo, gmina Wilczyn, pow. koniński, stan. 5. Grobowiec I. Rzut poziomy od SE po zdjęciu bruku (fot. K. Gorczyca)

Fig. 21. Ościsłowo, com. Wilczyn, Konin county, site 5. Barrow I. Layout, view to NW without cobblestones (photo by K. Gorczyca) 


\section{Pochówki i inwentarz}

Wyniki analiz antropologicznych oraz rozmiary grobów wskazują, że na cmentarzysku pochowano dzieci. Obecność inwentarza stwierdzono w 5 grobach. Wydaje się, że znalezione drobne fragmenty ceramiki i odłupki mogły dostać się do grobu przypadkowo i nie były intencjonalnym wyposażaniem grobowym. To samo można powiedzieć o fragmentach żaren, które zostały znalezione wśród kamieni w grobie 5.

\section{Hipotetyczne przyczyny różnic w obrządku pogrzebowym}

W KPL daje się zauważyć zróżnicowane podejście do grzebania zmarłych dzieci. Chowano je na przykład w jamach gospodarczych na osadach (Kukawka 1993, s. 85). Czasami, ale dość rzadko, traktowano je jak dorosłych i grzebano w grobach podobnych do tych dla dorosłych na wspólnych cmentarzyskach. Ostatnio odkryto takie w Małopolsce (Bargieł, Florek 2005, s. 20-32; Kozak-Zychman, Szeliga 2005, s. 33-41). Znane były także cmentarzyska, na których zarejestrowano tylko groby dzieci, na przykład w Małopolsce i Saksonii. Należało się spodziewać, że znajdą się takie również w Wielkopolsce (Wiślański 1979, s. 251).

Nie wiadomo, czy było to związane z wierzeniami, pozycją społeczną dziecka, czy po prostu cmentarzyska były porzucane, zanim zmarł ktoś dorosły. Przy ówczesnej śmiertelności wśród dzieci nie byłoby to czymś zaskakującym, podobnie jak ich liczba (Piasecki 1990, s. 30-35). Wydaje się, że cmentarzysko marianowskie należato do jednej rodziny.

Badania etnoarcheologiczne prowadzone w końcu XX w., dotyczące społeczeństw wytwarzających nadal naczynia w warunkach przydomowych, wskazują, że zajmowały się tym głównie kobiety. Regułą było przekazywanie umiejętności od matki do córki lub od babki do wnuczki, ale są znane przypadki, kiedy uczono osoby spoza klanu (Kobylińska, Kobyliński 1981, s. 43-53; Skibo 1992, s. 27-38). Przepływ wytworów materialnych (m.in. ceramiki) wiąże się w dużej mierze z zawieraniem małżeństw międzygrupowych (Hodder 1977, s. 239-269). Jest wysoce prawdopodobne, że tak było w przeszłości.

W tym świetle można pokusić się o próbę interpretacji obecności tzw. mątewskiego komponentu kulturowego w materiale ceramicznym na osadzie w Marianowie. Wydaje się możliwe wysunięcie przypuszczenia, że:

1. Naczynia wykonane w technologii „leśnej” i z ornamentyką pasmowo-grzebykową (nieliczne) zostały przyniesione przez kobietę (nową żonę?) z obcej grupy kulturowej z kręgu subneolitycznego (Kukawka 2010, s. 196-198).

2. Naczynia wykonane w technologii i z ornamentyką KPL, ale $\mathrm{z}$ niedużą domieszką thuczonych muszli (nieliczne), są odbiciem przystosowywania się tejże kobiety do obyczajów w nowej grupie kulturowej pod wpływem otoczenia (nowej rodziny?). 
3. Naczynia wykonane w klasycznej technologii i z ornamentyką KPL (liczne) wskazują na pełne przystosowanie się tej kobiety lub/i obecność drugiej kobiety (kobiet? - żony? teściowej?) z lokalnej grupy kulturowej KPL.

W tym kontekście można założyć, że mimo pełnej adaptacji w nowej grupie ta kobieta mogła być nadal postrzegana jako „obca”, podobnie jak urodzone przez nią dziecko. To wydaje się główną przyczyną zastosowania tak odmiennego obrządku pogrzebowego jak ciałopalenie (Gil-Drozd 2012, s. 361-369). Pozostałe dzieci, pochowane w klasyczny dla ludności KPL sposób, prawdopodobnie pochodzą z innego związku z kobietą z lokalnej grupy kulturowej.

Z podobną sytuacją, jak wspomniano, mamy do czynienia w Małem Czystem, gm. Stolno, gdzie także zaobserwowano ślady ciałopalenia w kontekście obecności w grobie tzw. mątewskiego komponentu kulturowego (Gurtowski 1987, s. 175-181; Kukawka, Wawrzykowska 1990, s. 40-44).

Wydaje się, że ciałopalne i częściowo ciałopalne groby z Sarnowa, stan. 1A, wskazują (Kapica 1986, s. 90-107; Wiklak 1986, s. 77-89), iż geneza tego sposobu traktowania zmarłych sięga już wczesnych faz KPL i mógł on mieć charakter powszechniejszy, niż się uważa.

\section{BIBLIOGRAFIA}

Baczyńska B.

1984 Dwa pochówki młodszej fazy kultury pucharów lejkowatych z Szarbii, woj. Kielce. Sprawozdania Archeologiczne, 36, s. 21-28.

Bargieł B., Florek M.

2005 Wyniki badań wykopaliskowych prowadzonych w latach 2001-2003 na cmentarzysku kultury pucharów lejkowatych w Pawłowie, stan. 3, pow. Sandomierz. Archeologia Polski Środkowowschodniej, 7, s. 20-32.

Bukowska-Gedigowa J.

1975 Kultura pucharów lejkowatych w dorzeczu górnej Odry. Przegląd Archeologiczny, 23, s. $83-186$.

Buśko C.

1987 Rekonstrukcja niektórych elementów obrządku pogrzebowego ludności kultury łużyckiej. Silesia Antiqua, 29, s. 59-93.

Gil-Drozd A.

2012 Kremacja sposobem grzebania „obcych”? Zagadnienie birytualizmu w młodszej epoce kamienia. W: W. Dzieduszycki, J. Wrzesiński (red.), Obcy. Funeralia Lednickie - spotkanie 14 (s. 361-369). Poznań: Stowarzyszenie Naukowe Archeologów Polskich. Oddział w Poznaniu.

Gorczyca K.

2005 Kleczewska enklawa grobowców kujawskich. Zarys problemu. Folia Praehistorica Posnaniensia, 13/14, s. 117-132.

Gorczyca K.

2008 Sprawozdanie z archeologicznych wykopaliskowych badan ratunkowych przeprowadzonych w Ościstowie, gm. Wilczyn, powiat Konin, woj. wielkopolskie, na stanowisku 5, AZP 52-40/150. [Maszynopis w archiwum Muzeum Okręgowego w Koninie, Konin]. 
Grygiel R.

1986 The household cluster as a fundamental social unit of the Lengyel Culture in the Polish Lowlands. Dom z podwórzem jako reprezentacja archeologiczna podstawowej jednostki społecznej w grupie brzesko-kujawskiej kultury lendzielskiej. Prace i Materiały Muzeum

Gurtowski P. Archeologicznego i Etnograficznego w Lodzi. Seria Archeologia, 31(1984), s. 43-334.

1987 Cmentarzysko ludności kultury pucharów lejkowatych w miejscowości Małe Czyste, gm. Stolno, stan. 20. W: T. Wiślański (red.), Neolit i początki epoki brąu na Ziemi Chetmińskiej. Materialy z międzynarodowego sympozjum, Toruń, 11-13 XI 1986 (s. 175-181). Toruń: Biuro Badań i Dokumentacji Zabytków.

Hodder I.

1977 The distribution of material culture items in Baringo district, western Kenya. Man, 12(2), s. 239-269.

Jakimowicz R.

1936 Kultura Śląska w zaraniu dziejów w świetle wykopalisk. Katowice: Wydawnictwa Instytutu Śląskiego.

Januszewski J.

1968 Przebieg roczny zgonów we wczesnym średniowieczu w świetle zmian klimatycznych.

Czasopismo Geograficzne, 39, s. 265-270.

Jażdżewski K.

1936 Kultura puharów lejkowatych w Polsce Zachodniej i Środkowej. Poznań: Polskie Towarzystwo Prehistoryczne.

Kapica Z.

1986 Identyfikacja antropologiczna pochówków z osady kultury pucharów lejkowatych (KPL) w Sarnowie (stan. 1A), woj. Włocławek. Sprawozdania Archeologiczne, 38, s. 90-107.

Kobylińska U., Kobyliński Z.

1981 Kierunki etnoarcheologicznego badania ceramiki: przegląd problematyki. Kwartalnik Historii Kultury Materialnej, 29(1), s. 43-53.

Kośko A.

1981 Udziat poludniowo-wschodnioeuropejskich wzorców kulturowych w rozwoju niżowych spoleczeństw kultury pucharów lejkowatych. Poznań: Wydawnictwo Naukowe Uniwersytetu im. Adama Mickiewicza w Poznaniu.

Kośko A., Prinke A.

1977 Sierakowo, woj. Bydgoszcz, stan. 8 - osada z fazy II (wczesnowióreckiej) kultury pucharów lejkowatych. Fontes Archaeologici Posnanienses, 26(1975), s. 1-42.

Kozak-Zychman W., Szeliga M.

2005 Pochówki z cmentarzyska ludności kultury pucharów lejkowatych w Pawłowie, stan. 3, pow. Sandomierz (badania 2001-2003 r.). Archeologia Polski Środkowowschodniej, 7, s. 33-41.

Krygowski B.

1961 Geografia fizyczna Niziny Wielkopolskiej, cz. 1, Geomorfologia. Poznań: Wydawnictwo Naukowe PWN.

Kukawka S.

1993 Zakrzewo, gmina Radzyń Chełmiński, stanowisko 6. Osada z I fazy rozwoju kultury pucharów lejkowatych na Ziemi Chełmińskiej. W: J. Grześkowiak (red.), Archeologiczne badania weryfikacyjno-sondażowe stanowisk neolitycznych na terenie województwa toruńskiego w latach 1992 i 1993 (s. 81-87). Toruń: Państwowa Służba Ochrony Zabytków, Oddział Wojewódzki w Toruniu. 
Kukawka S.

2010 Subneolit pótnocno-wschodnioeuropejski na Niżu Polskim. Toruń: Wydawnictwo Naukowe Uniwersytetu Mikołaja Kopernika.

Kukawka S., Wawrzykowska B.

1990 Małe Czyste, gmina Stolno, województwo toruńskie, stanowisko 20, grób 88. W:

D. Jankowska, Z badań nad chronologia absolutna stanowisk neolitycznych z ziemi chetmińskiej (s. 40-44). Toruń: Wojewódzki Ośrodek Ochrony Środowiska Kulturowego w Toruniu. Instytut Archeologii i Etnografii Uniwersytetu Mikołaja Kopernika w Toruniu.

Marciniak M.

1987 Osada kultury pucharów lejkowatych w Brodnicy-Szabdzie Cegielni, stan. 2. W: T. Wiślański (red.), Neolit i początki epoki brąu na Ziemi Chetmińskiej. Materiały z międzynarodowego sympozjum, Toruń, 11-13 XI 1986 (s. 167-174). Toruń: Biuro Badań i Dokumentacji Zabytków.

Nogaj-Chachaj J.

1991 The stone-packed graves of the Funnel Beakers culture in Karmanowice, site 35. Antiquity, 65(248), s. 628-639.

Pearson M.

1999 The Archaeology of Death and Burial. Texas A\&M University Press, College Station.

Piasecki E.

1990 Cmentarzyska w aspekcie demograficznym. Przegląd Archeologiczny, 37, s. 5-52.

Rzepecki S.

2004 Społeczności środkowoneolitycznej kultury pucharów lejkowatych na Kujawach. Poznań: Wydawnictwo Poznańskie.

Rybicka M.

1995 Przemiany kulturowe i osadnicze w III tys. przed. Chr. na Kujawach. Łódź: Muzeum Archeologiczne i Etnograficzne w Łodzi.

Skibo J.M.

1992 Ethnoarcheology, experimental archeology and inference building in ceramic research. Archaeologia Polona, 30, s. 27-38.

Wierzbicki J.

1994 Cmentarzysko ludności kultury pucharów lejkowatych w Łupawie, gm. Potęgowo, woj. Słupsk, stanowisko 15. Folia Praehistorica Posnaniensia, 6, s. 5-58.

Wierzbicki J.

1998 Dynamiczny model łupawskiego mikroregionu osadniczego (ŁMO) ludności kultury pucharów lejkowatych. Acta Archaeologica Pomoranica, 1, s. 53-67.

Wierzbicki J.

1999 Eupawski mikroregion osadniczy ludności kultury pucharów lejkowatych. Poznań: Wydawnictwo Naukowe Uniwersytetu im. Adama Mickiewicza w Poznaniu.

Wierzbicki J.

2008 Nowy typ cmentarzyska wielkopolskich społeczności kultury pucharów lejkowatych (Konarzewo, gm. Dopiewo, pow. Poznań, woj. wielkopolskie, stan. 5). Wielkopolskie Sprawozdania Archeologiczne, 9, s. 25-55.

Wierzbicki J.

2013 Wielka kolonizacja. Społeczności kultury pucharów lejkowatych $w$ dorzeczu środkowej Warty. Poznań: Stowarzyszenie Naukowe Archeologów Polskich. Oddział w Poznaniu.

Wiklak. H.

1986 Osada i cmentarzysko fazy sarnowskiej kultury pucharów lejkowatych na stan. 1A w Sarnowie, woj. Włocławek. Sprawozdania Archeologiczne, 38, s. 77-89. 
Wiślański T.

1979 Kształtowanie się miejscowych kultur rolniczo-hodowlanych. Plemiona kultury pucharów lejkowatych. W: W. Hensel, T. Wiślański, Prahistoria ziem polskich (t. 2, Neolit, s. 251-260). Wrocław-Warszawa-Kraków-Gdańsk: Ossolineum.

Woźny J.

2000 Symbolika przestrzeni miejsc grzebalnych $w$ czasach ciatopalenia zwlok na ziemiach polskich (od środkowej epoki brazu do środkowego okresu lateńskiego). Bydgoszcz: Wydawnictwo Uczelniane Wyższej Szkoły Pedagogicznej.

Wrzesińska A.

2006 Szczątki ludzkie ze stanowiska Marianowo 17, gmina Ślesin, powiat Konin, województwo wielkopolskie, Lednogóra 2006. [Maszynopis w archiwum Muzeum Okręgowego w Koninie, Konin].

\title{
CEMETERY OF THE FUNNEL BEAKER CULTURE COMMUNITY IN MARIANOWO, KONIN COUNTY, SITE 17
}

\author{
S u m m a r y
}

The site is located in Szyszynek, the location belonging to Marianowo village, com. Ślesin, Konin county (geographical coordinates N $52^{\circ} 25^{\prime} 7.38^{\prime \prime}$ E $18^{\circ} 17^{\prime} 8.83$ "). It is located on a small sandy elevation with its relative height of approximately $1.5 \mathrm{~m}$, not far from postglacial potholes.

Rescue excavations at the site were conducted in the seasons of 1988, 1989, 1990 and 1992. A total excavated area in four trenches covered 825 square metres. In trench III there was a TRB cemetery recorded, consisting of six graves. More than 800 fragments of pottery were collected, but their morphological (including those of collared flasks), technological and ornamentation features suggest that they represent an earlier stage of occupation, dating from "early Wiórek" phase. It should be assumed that they are not directly related to the cemetery. Only several small potsherds (eight), and flint flakes, occurred in the graves, however, they could have got there accidentally. The only dating artefact could be a fragment of a rim found in grave 3, decorated with a motif of vertical bars underlined with an incised zigzag. The cemetery most probably should be linked with the second phase of the occupation of the site when the settlement recorded in trench I was inhabited (it will be the subject of a separate study). The analysis of the ornamentation on pottery, with the elements of Wielkopolska component in an Epi-Wiórek version, whilst without a corded decorative motif suggests that the settlement could have been occupied in the period limited to the sub-phase IIIC.

The graves were located in the vicinity of buildings of a single homestead village $-130 \mathrm{~m}$ to the NNW of it. This suggests that there was a connection between the two places. That the cemetery belonged to this "house with a yard" and was intended for its inhabitants exclusively. The graves were in-lined, oriented is almost the same direction, almost parallel to E-W axis. According to the organisation of stones in graves, the corpses were laid with their heads eastwards, and only in grave 5 a head was found in west part of the grave. 
Each of the graves in Marianowo had a slightly different construction pattern:

1. trapezoidal enclosure similar in its shape to a Kujavian barrow (G1),

2. trapezoidal enclosure, cobbled (G2);

3. rectangular enclosure, cobbled (G4);

4. rectangular cobble (G6);

5. trapezoidal (originally probably rectangular) pit with walls stone-lined (so-called dry wall) (G5);

6. elongated, oval, shallow pit, with a circular pit, $\mathrm{C}$-shaped in its cross-section, at the east end containing the cremation burial (G3).

The first four graves do not differ significantly from other burials known from the eastern group. Graves with stone-lined walls (so-called dry walls) are quite rare, but occur in many areas, such as Małopolska or Pomerania. Almost all the graves in Marianowo contained buried children. The only exception is a cremation burial. Its larger pit resembles shallow pits of inhumation graves, but no bones have been found in it. Its closest analogy is the grave in Małe Czyste, com. Stolno. Cremations occur within almost the entire area occupied by the TRB communities, although very rarely. Only in the Middle Pomerania and in the late stages also in Upper Silesia and Moravia this cremation rite becomes dominant.

Ethnoarchaeological study conducted among communities producing vessels in household conditions revealed that they are women mainly responsible for manufacturing pottery. As a rule the skill is transferred from mother to daughter or from grandmother to her granddaughter. The transfer of material objects (including pottery) is associated mainly with intergroup marriages. It seems probable that it was the case also in the past. It permits interpretation of the presence of socalled "Mątwy cultural component" in the ceramic material at Marianowo settlement. Possible explanations are:

1. vessels made in the "forest" technology and with band and comb ornamentation (few) were brought by the woman (a new wife?) from a foreign cultural group from the subneolithic circle,

2. vessels produced in the TRB technology and with its ornamentation, but with some temper of crushed shells (few), reflect the woman's attempts to adapt to new habits in a new cultural group under the influence of her surroundings,

3. vessels made in the classic TRB technology and with its ornamentation (numerous) indicate the woman's complete adaptation and/or the presence of another one from the local cultural group of TRB.

It might be assumed that, in spite of full adaptation to a new group, this woman could have been still seen as a "stranger", just like a child she gave birth to. This seems to be the main reason for the use of a different burial rite, cremation, in the case of the child. The other children, buried in a typical TRB rite were probably born as a result of the other relationship, with a woman from a local cultural group. 